\title{
回転中心指定型ロッキング機構並びに構造物のモード制御 ROCKING CENTER DESIGNATED MECHANISM AND STRUCTURE CONTROL
}

\author{
張 富明* \\ Fuming ZHANG
}

\begin{abstract}
Rocking Center Designated (RCD) Mechanism is proposed as a tool to control the vibration modes of structures. An ideal RCD mechanism is simply a rigid body guided on a sphere surface, and the rocking center of the rigid body is decided and designated by the curvature of the sphere surface. And the RCD mechanism can also be realized by replacing vertical columns in soft story structure by diagonal columns that pointed to the rocking center. If the RCD mechanism is incorporated into a structure, the vibration modes of the structure can be designated and the input of motions at a specific position can be controlled. In this paper, RCD mechanism and its effectiveness in structure control are explained. Structure using the concept of RCD mechanism is expected to be a new strategy for eliminating damage of civil structures during intense earthquakes.
\end{abstract}

Key words: rocking center designated mechanism, vibration mode, earthquake, response, input reduction, structure control 回転中心指定型ロッキング機構，振動モード，地震，応答，入力低減，制振構造

\section{1.はじめに}

昨今、制振構造の研究が目賞しい成果を遂げている。中でも、免 震構造が普及の段階に入り、層間ダンパーを利用したパッシブ型制 振構造が性能設計の一つの有力なツールとしてますます多く適用 されるようになってきた。しかし、制振構造の積極的な研究開発に 対し、構造システムに関する研究は少なく、制振構造に適する構造 システムの提案も少ないのが現状である。

通常の梁降伏型の構造システムでは逆三角形のような 1 次振動 モードが卓越し、層間ダンパーを利用したパッシブ型制振構造はこ のような構造システムに減衰を付加し、応答の低減を図ろうとして いる。しかし、層間ダンパーを利用したパッシブ型制振構造は数多 くのダンパーを適切に配置しなければならない。また、各層にダン パーの量を適切に配置し、ダンパーを均等に効力を発揮させること は容易なことではなく、更に、ダンパーは目標層間変形の制限を受 けなければならない。

一方、基礎免震構造では変形が免震層に集中し、矩形に近い台 形のような 1 次振動モードが卓越する。免震構造は固有周期の調 整と共に、振動モードの制御も図られている。変形を免震層に集 中させることは免震構造の特徵ではあるが、鉄骨構造の場合に上 部構造にも一定の変形を分担させる必要があること、免震層の応 答変形を小さくすることなどの要望も考えられる。しかし、上部 構造と免震層の剛性が比例しないために、変形の配分は容易なこ
とではない。同じく、ピロティー建物も同様な問題が存在する。

以上のように、従来構造の 2 種類の卓越振動形に対して、それ らの中間型、あるいは任意形状の振動モードを示す構造システム は末だ提案されていない。換言すれば、従来の耐震設計（層間夕゙ ンパーを利用したパッシブ型制振構造を含む）と基礎免震構造の 設計思想が連続していない。構造物の振動モードを指定できれば、 構造設計の自由度が広げられ、様々な可能性が生まれる。

本研究は、構造物の回転中心を指定することにより、振動モ一 ドを自由に規定できる「回転中心指定型ロッキング（RCD）機構」 を提案し、その振動特性及び応答性状を検討する。 RCD 機構は構 造システムであり、構造物の応答を制御できる制振構造でもある。 $\mathrm{RCD}$ 機構及びそれを組み込んだ構造システムは振動モード制御 の他に、固有周期の調整、構造物に対する入力低减などの特徵が ある。

本報は、まず RCD 機構の効用を説明するために、剛体モデル を用い、調和外力及び地震動を受ける場合の RCD 機構の応答性 状を検討する。次に、固有值解析を行い、RCD 機構を組み込んだ RCD 構造の振動性状を検討する。

\section{2. 回転中心指定型ロッキング（RCD）機構}

$2.1 \mathrm{RCD}$ 機構及びその振動モード

Fig.1に回転中心指定型ロッキング（RCD）機構（Rocking

\footnotetext{
* 松村組技術研究所 工博 
Center Designated mechanism）の概念図を示す。RCD 機構は 剛体がある曲率半径 Rを持つ曲面にガイドされ、ロッキング中心 に向かって曲面上で運動する機構である。曲面の曲率半径 R は㴊 体の回転半径でもあり、ロッキング中心は曲面の曲率中心に一致 し曲面との間に相対変形を生じない。

剛体の質量を $m$ 、重心 $G$ の高さを $s$ 、重心回りの回転剛性を $I_{G}$ とし、曲面の曲率中心を $C$ とする。ある方向の運動に対し、 剛体は地盤上の曲面に沿ってある回転角 $\theta$ が生じた場合、重心 $G$ での地盤との相対水平変位 $x$ は次のようになる。

$$
x=(s-R) \cdot \theta
$$

また、剛体と曲面の間に、回転半径の接線方向の相対変位 $x_{R}$ 、 重心から距離 $l$ にある点の相対水平変位 $x_{l}$ は次のようになる。

$$
\begin{aligned}
& x_{R}=-R \cdot \theta \\
& x_{l}=(s+l-R) \cdot \theta=\frac{(s+l-R)}{(s-R)} x
\end{aligned}
$$

剛体と曲面の間に、回転半径の接線方向に沿うばねの剛性の和 を $K_{R}$ とする。地震動などで、地盤の運動 $x_{0}$ がある時に、回転中 心指定型ロッキング機構の運動エネルギー $E$ と歪エネルギー $V$ は下記の式となる。

$$
\begin{aligned}
E & =\frac{1}{2} m\left(\dot{x}+\dot{x}_{0}\right)^{2}+\frac{1}{2} I_{G} \dot{\theta}^{2} \\
& =\frac{1}{2} m(s-R)^{2} \cdot \dot{\theta}^{2}+\frac{1}{2} I_{G} \dot{\theta}^{2}+m(s-R) \cdot \dot{\theta} \cdot \dot{x}_{0}+\frac{1}{2} m \dot{x}_{0}^{2} \\
V & =\frac{1}{2} K_{R} \cdot x_{R}^{2}=\frac{1}{2} K_{R} \cdot(R \theta)^{2}
\end{aligned}
$$

運動方程式は次のように導かれる。

$$
\begin{aligned}
& \frac{d(\partial E / \partial \dot{\theta})}{d t}+\frac{\partial V}{\partial \theta}=0 \\
& m(s-R)^{2} \cdot \ddot{\theta}+I_{G} \ddot{\theta}+m(s-R) \cdot \ddot{x}_{0}+K_{R} R^{2} \theta=0
\end{aligned}
$$

重心 $G$ での相対水平変位 $x$ で表わすと、運動方程式は次のよう になる。

$$
\begin{aligned}
& {\left[m(s-R)+\frac{I_{G}}{s-R}\right] \ddot{x}+K_{R} \frac{R^{2}}{s-R} x+m(s-R) \ddot{x}_{0}=0} \\
& {\left[1+\frac{I_{G}}{m(s-R)^{2}}\right] \cdot m \cdot \ddot{x}+K_{R} \frac{R^{2}}{(s-R)^{2}} x=-m \cdot \ddot{x_{0}}}
\end{aligned}
$$

更に、運動方程式を次の形で表わす。

$$
\ddot{x}+\omega_{R}{ }^{2} x=-\alpha \ddot{x_{0}}
$$

なお、固有振動数 $\omega_{R}$ 、地震入力の低隇率 $\alpha$ は下記のように回 転半径 $R$ などの関数で表わされる。

$$
\begin{aligned}
& \omega_{R}^{2}=\frac{\left(\frac{R}{s-R}\right)^{2}}{1+\frac{I_{G}}{m(s-R)^{2}}} \cdot \frac{K_{R}}{m}=\frac{1}{\beta_{T R}^{2}} \cdot \omega_{I}^{2} \\
& \alpha=\frac{(s-R)^{2}}{(s-R)^{2}+I_{G} / m} \\
& \beta_{T R}=\sqrt{\frac{(s-R)^{2}+I_{G} / m}{R^{2}}} \\
& \omega_{I}=\sqrt{\frac{K_{R}}{m}}
\end{aligned}
$$

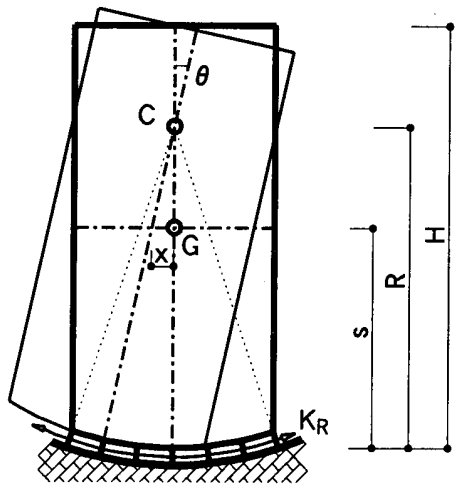

Fig.1 RCD Mechanism

$\omega_{I}$ は免震構造に対応する。式(3)を式(10)に代入すると、任意 位置での相対水平変位 $x_{l}$ に対する運動方程式は式(15)で表わされ る。 $\alpha_{l}$ は位置 $l$ における地震入力の比率一入力係数で、式(16)で 表わされる。

$$
\begin{aligned}
& \ddot{x}_{l}+\omega_{R}{ }^{2} x_{l}=-\alpha_{l} \ddot{x}_{0} \\
& \alpha_{l}=\frac{(s+l-R)}{(s-R)} \alpha=\frac{(s-R)(s+l-R)}{(s-R)^{2}+I_{G} / m}
\end{aligned}
$$

$\mathrm{RCD}$ 機構の効果を定量的に説明するために、構造物の質量が高

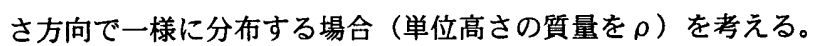
重心の高さは $s=H / 2$ であるので、床レベルの回転慣性を無視す ると、重心回りの回転慣性 $I_{G}$ は式(17)となる。また、入力低減率 $\alpha$ を式(18)で表わすことができる。

$$
\begin{aligned}
& I_{G}=2 \int_{0}^{H / 2} \rho l^{2} d l=\frac{2}{3} \rho(H / 2)^{3}=\frac{1}{12} m H^{2} \\
& \alpha=\frac{(1-2 R / H)^{2}}{(1-2 R / H)^{2}+1 / 3}=\frac{(1-R / s)^{2}}{(1-R / s)^{2}+1 / 3}
\end{aligned}
$$

Fig. 2 に頂部、重心、底部位置での入力係数 $\alpha_{t} 、 \alpha 、 \alpha_{b}$ と口 ッキング半径と重心高さの比 $R / s$ の関係を示す。 $\alpha$ は 1 より小

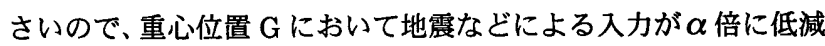
されることになる。また、ロッキング半径と重心の高さ比 $R / s=1$ の時、すなわち曲率中心が回転剛性の中心 $\mathrm{G}$ に一致する 場合、 $\alpha=0$ となり、 $\mathrm{RCD}$ 機構に相対変位が生じることがなく、 地盤と全く同じ運動をする。

固有周期と減衰定数が等しい通常の 1 質点の応答変形に対し、 $\mathrm{RCD}$ 機構では任意位置の相対水平応答変形は当該位置の入力係

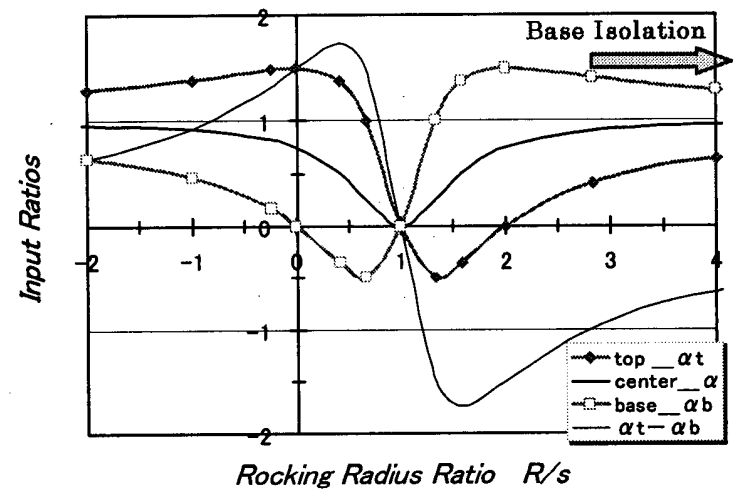

Fig.2 Input Ratios of Relative Displacement 
数 $\alpha_{l}$ の倍数となるので、 $\alpha_{l}\left(-0.5 \leq \alpha_{l} \leq 1.5\right)$ は剛体の振動形を表 わすものである。Fig. 3 に示すように、 $R= \pm \infty$ の場合、RCD 機 構は一様に変形する振動形を示し、上部構造が剖な基礎免震構造 と同じような振動形を示す。 $R$ がー学增えていくと、頂部の 変形が大きい台形分布を示す。これはいわゆるソフトストーリ建 物の 1 次モードと同じような振動形であるが、通常のソフトスト 一リ建物は能動的に振動形を指定できない。 $R$ が 0 となると振動 形は逆三角形分布、 $R / s$ が 0 2 の間の場合には頂部と底部が逆 に変形する振動形、 $R / s=2$ の場合には三角形、 $R$ が更に增える と底部の変形が大きい台形を示す。このように、 $R / s$ の值すなわ ち RCD 機構の回転中心により、直線状ではあるが、剛体の振動 形を任意に設定することが可能である。従って、RCD 機構を用い ることによって、剛体の振動形を制御することができる。また、 式(10)の運動方程式の入力低減率 $\alpha$ に着目すれば、本構造システ ムは一種の制振構造でもある ${ }^{1}$ 。

\section{2 調和地動を受ける場合の RCD 機搆}

振動数が $p$ である調和地動 $x_{0}=D_{0} e^{i p t}$ を受ける場合、減衰項を 導入し、式(10)に示す重心位置における RCD 機構の運動方程式は (19)式になる。

$$
\ddot{x}+2 h \omega x+\omega_{R}{ }^{2} x=\alpha D_{0} p^{2} e^{i p t}
$$

定常振動について解くと、重心位置での相対変位応答倍率及び 絶対加速度応答倍率は式(20)、(21)となる。

$$
\left|\frac{x}{D_{0}}\right|_{\max }=\frac{\alpha\left(p / \omega_{R}\right)^{2}}{\sqrt{\left[1-\left(p / \omega_{R}\right)^{2}\right]^{2}+4 h^{2}\left(p / \omega_{R}\right)^{2}}}
$$

$$
\left|\frac{\ddot{x}+\ddot{x}_{0}}{\mid \ddot{x}_{0}}\right|=\frac{\sqrt{\left\{\left[1-\left(\frac{p}{\omega_{R}}\right)^{2}\right] \cdot\left[1-(1-\alpha)\left(\frac{p}{\omega_{R}}\right)^{2}\right]+4 h^{2}\left(\frac{p}{\omega_{R}}\right)^{2}\right\}^{2}+4 \alpha^{2} h^{2}\left(\frac{p}{\omega_{R}}\right)^{6}}}{\left[1-\left(p / \omega_{R}\right)^{2}\right]^{2}+4 h^{2}\left(p / \omega_{R}\right)^{2}}
$$

式(20)に示すように、通常の 1 質点系 $(\alpha=1)$ に比べ、重心位 置での相対変位の応答倍率は入力低減率の $\alpha$ 倍だけ小さくなる。 一方、重心位置での絶対加速度応答倍率は Fig.4 に示すように、 通常の 1 質点系に比べ、振動数比 $p / \omega_{R}$ が小さい領域に減少する が、 $p / \omega_{R}$ が大きい長周期領域には增大する。その境となる振動 数比は減衰定数 $h$ と入力低減率 $\alpha$ によって変わる。特に、減衰が 0 で、式(22)に示す振動数比の場合には重心位置での絶対加速度 応答倍率は 0 となる。当然、この場合、 $\mathrm{RCD}$ 機構に回転成分の加 速度が存在する。

$$
\left(p / \omega_{R}\right)_{0}=\sqrt{\frac{1}{1-\alpha}}
$$

従って、調和地動を受ける場合、RCD 機構を用いて剛体の重心 位置でのの絶対加速度を大幅に低隇させることができる。

\section{3 地震動を受ける場合の RCD 機構}

次に、式(19)の運動方程式を用い、地震動 $x_{0}$ を受ける場合の $\mathrm{RCD}$ 機構の応答性状を検討する。運動方程式は式(23)となるが、 相対変位が $y$ である通常の 1 質点系の運動方程式は式(24)で表わ される。両者の相対変位の間に式（25）の関係が成り立つ。
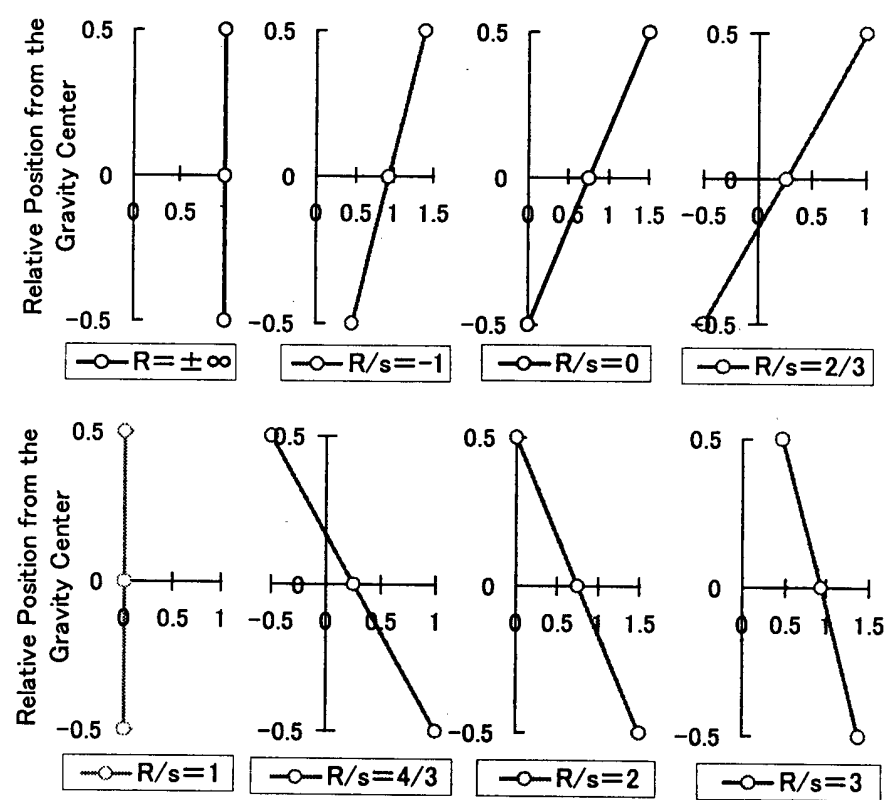

Fig.3 Vibration Shape $\alpha$, at Horizontal Direction
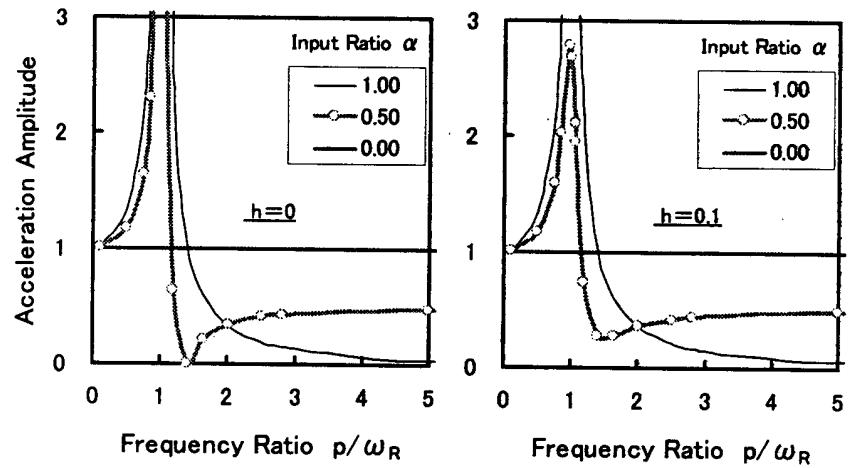

Fig.4 Absolute Acceleration Amplitude at Gravity Center

$$
\begin{aligned}
& \ddot{x}+2 h \omega \dot{x}+\omega_{R}{ }^{2} x=-\alpha \ddot{x_{0}} \\
& \ddot{y}+2 h \omega \dot{y}+\omega_{R}{ }^{2} y=-\ddot{x_{0}} \\
& x=\alpha \cdot y
\end{aligned}
$$

従って、RCD 機構の重心位置の絶対加速度を次式のように表わ すことができる。

$$
\begin{aligned}
& \ddot{x}+\ddot{x_{0}}=-2 h \omega \dot{x}-\omega_{R}{ }^{2} x+(1-\alpha) \ddot{x_{0}} \\
& =-\alpha\left(2 h \omega \dot{y}+\omega_{R}{ }^{2} y\right)+(1-\alpha) \ddot{x_{0}}=\alpha\left(\ddot{y}+\ddot{x_{0}}\right)+(1-\alpha) \ddot{x_{0}}
\end{aligned}
$$

通常の 1 質点系の絶対加速度応答倍率を $\beta_{1} 、 \mathrm{RCD}$ 機構の重心 位固の絶対加速度応答倍率 $\beta$ を SRSS 法で評価し、(27)式で表わ すこととする。

$$
\beta=\sqrt{\left(\alpha \beta_{1}\right)^{2}+(1-\alpha)^{2}}<\alpha \beta_{1}+(1-\alpha)
$$

入力地震動は El Centro 1940,NS を用い、地動最大加速度を $500 \mathrm{~cm} / \mathrm{s}^{2}$ とする。Fig.5 に計算結果を示す。 RCD 機構の重心位置 での相対変位は式(25)で示す通り、通常の 1 質点系の $\alpha$ 倍となる。 また、通常の 1 質点系に比べ、重心位直での絶対加速度応答倍率 $\beta$ は固有周期が比較的短い領域では减少するが、固有周期が比較 的長い領域では逆に増加する。固有周期に関わらず、 $\beta$ はSRSS 法（式(27)）でほぼ評価できる。 

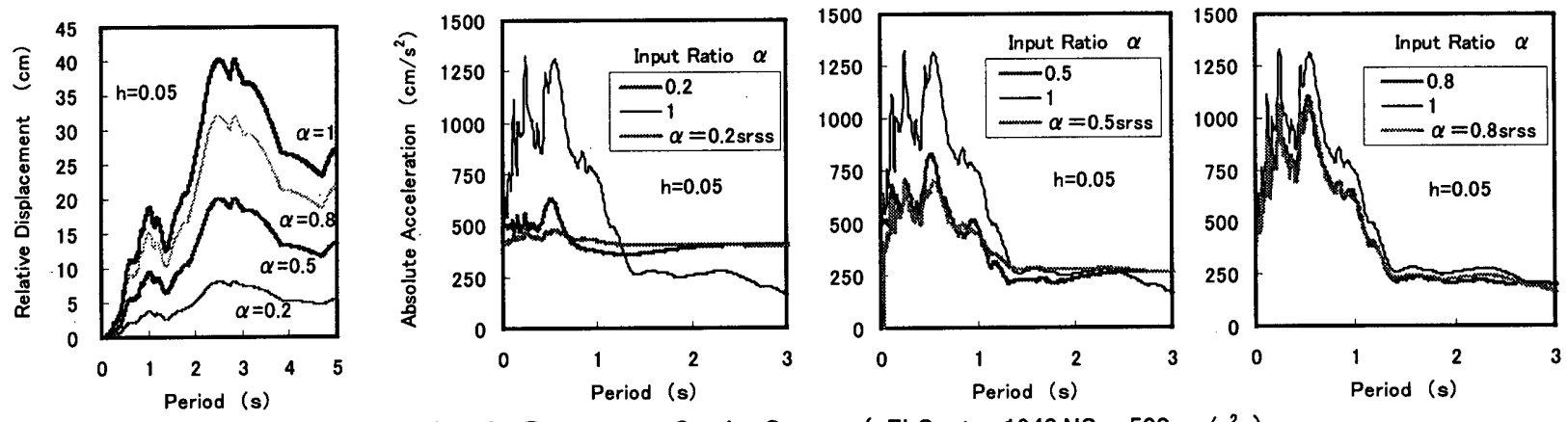

Fig.5 Earthquake Response at Gravity Center (El Centro 1940,NS, $500 \mathrm{~cm} / \mathrm{s}^{2}$ )
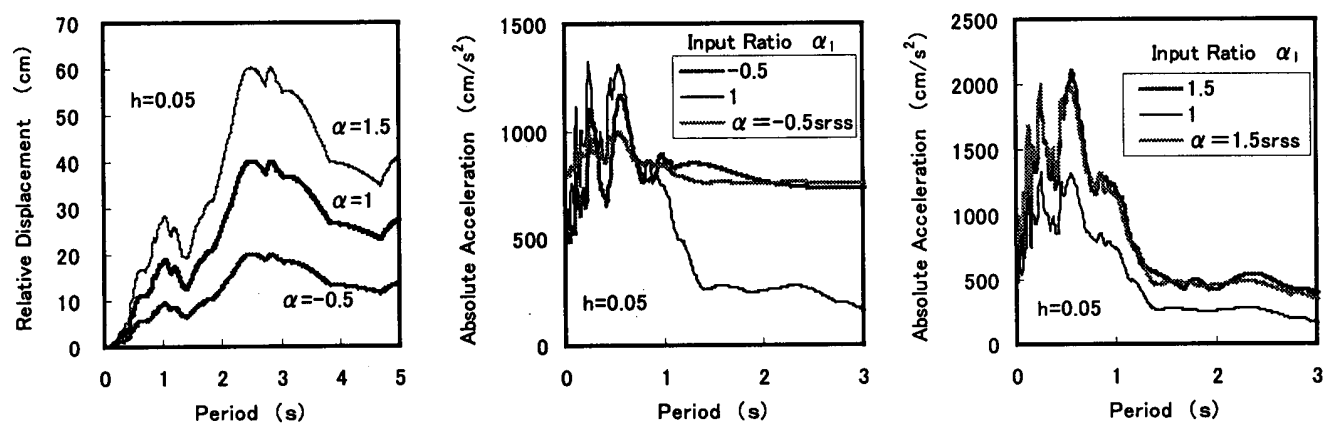

Fig.6 Earthquake Response for Different Input Ratio (El Centro 1940,NS, $500 \mathrm{~cm} / \mathrm{s}^{2}$ )

式(27)において、 $\beta=\beta_{1}$ と置くと、通常の 1 質点系に比べて重 心位置での絶対加速度応答倍率 $\beta$ が增隇する境界点（固有周期 $T_{0}$ ) の入力低隇率 $\alpha_{0}$ は式(28)で与えられる。

$$
\alpha_{0}=\frac{1-\beta_{1}^{2}}{1+\beta_{1}^{2}}
$$

Fig.5 と合わせ、式(28)の物理的な意味は次のように解积される。 $\mathrm{RCD}$ 機構は通常の 1 質点系（応答倍率 $\beta_{1}$ ) よりも小さい絶対加 速度応答倍率を得られるためには、 $T \leq T_{0}$ の領域においては $\alpha \leq \alpha_{0} 、 T>T_{0}$ の領域においては $\alpha>\alpha_{0}$ としなければならない。 従って、長周期領域では、 RCD 機構の効果は振動形の調整にあり、 地震力の低減はあまり期待できない。

$\mathrm{RCD}$ 機構の重心位置での応答はベースシャなど平均的な意味 合いを持つ。任意位置での応答（水平相対変位、絶対加速度）は、 重心位置の入力低隇率 $\alpha$ の代わりにその位置の入力係数 $\alpha$ （式 16)）を、式（25）と式(27)に代入して求めることができる。Fig.6 に示すように、同様に SRSS 法で評価できる。

ここでは、RCD 機構の原理を説明するために、Fig.1 に示す剛 体を用いた。後の 3 章での検討か5、Fig.3 の振動形は 1 次モ一 ドであり、 $\alpha_{1}$ はその刺激関数である。モーダルアナリシスによれ ば、周期が 0 である 2 次モードの刺激関数は $\alpha_{l}$ の補関数 $\left(1-\alpha_{l}\right)$ で あるために、式(27)は通常の 2 自由系に対する表現にすぎない。

上記の並進的な応答に続き、 $\mathrm{RCD}$ 機構の回転成分を検封する。 まず、全体回転角 $\theta$ は次式で求められる。

$$
\theta=\frac{\left(\alpha_{t}-\alpha_{b}\right) y}{H}=\frac{2(1-2 R / H)}{(1-2 R / H)^{2}+1 / 3} \cdot \frac{y}{H}=\beta_{\theta} \frac{y}{H}
$$

式(18)を用い、 $\beta_{\theta}$ は次式のように $\alpha$ の関数となる。

$$
\beta_{\theta}=\frac{2(1-2 R / H)}{(1-2 R / H)^{2}+1 / 3}= \pm 2 \sqrt{3 \alpha(1-\alpha)}
$$

$\beta_{\theta}\left(=\alpha_{t}-\alpha_{b}\right)$ は Fig. 2 に示すように、 $\pm \sqrt{3}$ の範囲内にある。 なお、 $R / s=0$ 、すなわち、逆三角形振動形の場合、 $\beta_{\theta}=1.5$ と なる。Fig.3 の振動形にも示されるように、ロッキング中心の指 定により、RCD 機構は回転角を制御することができる。

\section{3. モード指定型制振構造}

\subsection{RCD 構造}

2 章では、Fig.1に示した剛体モデルを用いて RCD 機構の原理 と効果を説明した。次に、平面的な RCD 機構を構面に組み込ん だ構造－RCD 構造の振動性状を検討する。

Fig.7 7 に示すように、平面的な RCD 機構は 2 階以上の剛性が 大きい変形制御壁とその下に取り付けられる斜柱から構成される。 両端ピンの斜柱は勿論のこと、両端剛接の斜柱を用いても、斜柱 の軸方向の剛性が高く、その直交方向に適度のせん断剛性と変形 能力を付与すれば、 $\mathrm{RCD}$ 機構は実現可能である。このような平面 的な $\mathrm{RCD}$ 機構を建物の両方向にそれぞれ配置し、 RCD 機構を比 較的簡単に建物の中に取り入れることができる。当然、それぞれ の方向に配置される RCD 機構は互いの変形を拘束し合わないよ うに、䇬接させないなどの工夫が必要である。また、同一方向に おいて、各 RCD 機構のロッキング中心を同じ高さに設定する必 要がある。

$\mathrm{RCD}$ 構造において、 $\mathrm{RCD}$ 機構の効用は 2 階以上の主体構造に 回転中心と同じ高さ位置に対する回転運動を強制的に与えること にある。これを Fig.8 の 1 質点系にモデル化する。ここでは、各 階の質量が等しく、各床レベルの回転慣性を無視して式(17)に示 す分布質量系の回転剛性を用いる。なお、主体構造について、回 転剛性を $k \cdot s^{2} 、 1$ 階のせん断剛性を $k_{1}$ 、階高を $h 、 R C D$ 機構に ついて、変形制御壁のせん断剛性を $k_{c}$ 、斜め柱の軸剛性を $E A$ 、 変形制御壁の幅を $L$ とする。また、 2 階床レベルの水平相対変形 を $x_{1}$ 、重心位置の水平相対変形を $x$ とし、変形制御壁のせん断ひ 

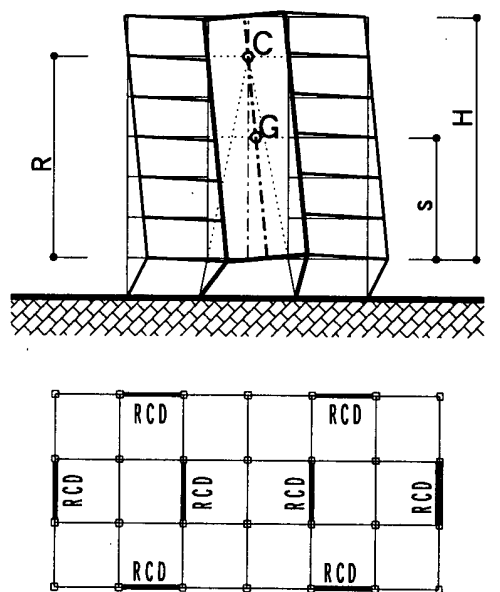

Fig.7 RCD Structure and RCD Mechanism

ずみを $\gamma_{c}$ とすれば、主体構造の回転角は剛体モデルの回転角 $\theta$ と $\gamma_{c}$ の和で与えられる。

\section{$3.2 \mathrm{RCD}$ 機構の用性が無限大の場合}

2 章の剛体モデルと比較する、ために、まず、Fig.8 の解析モデル において、RCD 機構の諸剛性を無限大と仮定する。

系の歪エネルギーVを次式で表わすことができる。

$V=\frac{1}{2} k_{1} x_{1}^{2}+\frac{1}{2} k s^{2} \theta^{2}=\frac{1}{2} k_{1}(R \theta)^{2} \cdot\left[1+\left(\frac{k}{k_{1}}\right) \cdot\left(\frac{s}{R}\right)^{2}\right]$

系の運動エネルギーは 2 章と同じように表現できるので、 2.1 節と同様な方法で、RCD 構造の運動方程式を次式で表わすことが できる。

$$
\begin{aligned}
& \ddot{x}+\omega_{\theta}^{2} x=-\alpha \ddot{x}_{0} \\
& \omega_{\theta}{ }^{2}=\frac{\left[k / k_{1}+(R / s)^{2}\right] \cdot k_{1}}{\left[(1-R / s)^{2}+1 / 3\right] \cdot m} \\
& T_{\theta}=\frac{2 \pi}{\omega_{\theta}}
\end{aligned}
$$

固有振動数 $\omega_{\theta}$ 以外は剛体モテルとまったく同じ結果となるの で、 RCD 機構の諸剛性を無限大とした場合、 $\mathrm{RCD}$ 構造は 2 章の 剛体モテルの結果を適用できる。

\section{$3.3 \mathrm{RCD}$ 機構の剛性を考慮した場合}

次に、RCD 機構の剛性を考虑した場合、Fig.8 の解析モテルルの 固有值解析を行う。まず、斜め柱の長さを $l_{0}$ 、傾きを $\varphi$ とし、水 平変位の適合条件、斜め柱の軸方向変形 (左側 $\Delta_{L}$ 、右側 $\Delta_{R}$ ) は 下記のように表わせる。

$$
\begin{aligned}
& \tan \varphi=\frac{L}{2 R} \\
& x=x_{1}+s\left(\theta+\gamma_{c}\right) \\
& \Delta_{L}=x_{1} \sin \varphi+\theta \frac{L}{2} \cos \varphi=-\Delta_{R}
\end{aligned}
$$

系の運動エネルギー $E$ とひずみエネルギーVを次のように表

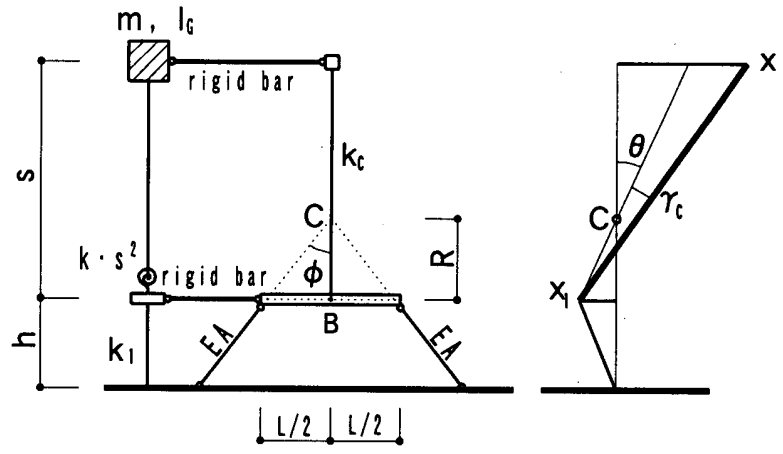

Fig.8 Analytical Model of RCD Structure

わすことができる。

$$
\begin{aligned}
& E=\frac{1}{2} m\left(\dot{x}+\dot{x}_{0}\right)^{2}+\frac{1}{2} I_{G}\left(\dot{\theta}+\dot{\gamma}_{c}\right)^{2} \\
& V=\frac{1}{2} k_{1} x_{1}^{2}+\frac{1}{2} k s^{2}\left(\theta+\gamma_{c}\right)^{2}+\frac{1}{2} k_{c}\left(s \gamma_{c}\right)^{2}+\frac{E A}{l_{0}} \Delta_{L}^{2}
\end{aligned}
$$

2 章と同様に、エネルギーの微分を求め、次の式が得られる。

$$
\begin{aligned}
& m\left(\ddot{x}+\ddot{x}_{0}\right)+k_{1} x_{1}+\frac{2 E A \sin \varphi}{l_{0}} \Delta_{L}=0 \\
& s m\left(\ddot{x}+\ddot{x}_{0}\right)+\frac{I_{G}}{s}\left(\ddot{x}-\ddot{x}_{1}\right)+k s\left(x-x_{1}\right)+\frac{E A L \cos \varphi}{l_{0}} \Delta_{L}=0 \\
& s m\left(\ddot{x}+\ddot{x}_{0}\right)+\frac{I_{G}}{s}\left(\ddot{x}-\ddot{x}_{1}\right)+k s\left(x-x_{1}\right)+k_{c} s^{2} \gamma_{c}=0
\end{aligned}
$$

斜柱の軸力 $N_{L}$ 、変形制御壁のせん断力 $Q_{c}$ は下記の式となる。

$$
\begin{aligned}
& N_{L}=\frac{E A}{l_{0}} \Delta_{L} \\
& Q_{c}=k_{c} s \gamma_{c}
\end{aligned}
$$

式(41)と(42)より、下記の式が得られる。

$$
\frac{E A L \cos \varphi}{l_{0}} \Delta_{L}=k_{c} s^{2} \gamma_{c}
$$

(45)式と(43)及び(44)式、更に(35)式を用い、 $N_{L}$ と $Q_{c}$ 間に次の 関係が成り立つ。

$$
N_{L} \cos \varphi L=Q_{c} s
$$

上の式は RCD 機構について、2 階レベルにおける曲げモーメ ントの釣り合い式である。同様に、(40)式は 1 階での水平力の釣 り合い式、(41)と(42)式は主体構造の曲げバネ位置に対する曲げ モーメントの釣り合い式である。

式(45)及び式(36)と(37)を用い、変形制御壁のせん断ひずみ $\gamma_{c}$ を次のように表わせる。

$$
\gamma_{c}=r_{e f}\left(\frac{x-x_{1}}{s}-\frac{x_{1}}{R}\right)
$$

ここでは、 RCD 機構の有効係数 $r_{e f}$ は斜柱の凨性を無限大とし た場合に対する変形制御壁のせん断ひずみの低減率を表わし、次 式で与えられる。

$$
r_{e f}=\frac{1}{1+\frac{k_{c}}{2 E A / h} \cdot\left(\frac{s}{L / 2}\right)^{2} \cdot\left[1+\left(\frac{L}{2 R}\right)^{2}\right]^{3 / 2}}
$$


従って、 $r_{e f}$ が小さいと、変形制御壁及び $\mathrm{RCD}$ 機構の機能が低 下することを意味する。

(40)と(41)式を整理すると、 $x_{1} 、 x$ に関する下記のような運動 方程式が得られる。系は 2 自由度システムである。

$$
\begin{aligned}
& m\left(\ddot{x}+\ddot{x}_{0}\right)+k_{11} x+k_{12} x_{1}=0 \\
& m\left(\ddot{x_{1}}+\ddot{x}_{0}\right)+k_{21} x+k_{22} x_{1}=0
\end{aligned}
$$

ここでは、剛性マトリックスの各項は次のようになる。

$$
\begin{aligned}
& k_{11}=\gamma_{e f} k_{c} \frac{s}{R} \\
& k_{12}=k_{1}+\gamma_{e f} k_{c} \frac{s}{R}\left(\frac{s}{R}-1\right) \\
& k_{21}=\gamma_{e f} k_{c}\left(4 \frac{s}{R}-3\right)-3 k \\
& k_{22}=4 k_{1}+3 k+\gamma_{e f} k_{c}\left(\frac{s}{R}-1\right)\left(4 \frac{s}{R}-3\right)
\end{aligned}
$$

$\mathrm{RCD}$ 構造の固有振動数、固有モードは次のようになる。

$$
\begin{aligned}
& \omega_{1,2}^{2}=\frac{1}{2 m}\left[k_{11}+k_{22} \mp \sqrt{\left(k_{11}+k_{22}\right)^{2}-4\left(k_{11} k_{22}-k_{12} k_{21}\right)}\right] \\
& \frac{X_{1}}{X}=\frac{m \omega_{1,2}^{2}-k_{11}}{k_{12}}
\end{aligned}
$$

また、本解析モデルは均等分布質量系に対するものであるので、 重心位置での刺激関数 ${ }_{i} \alpha$ と 2 階床位置での刺激関数 ${ }_{i} \alpha_{b}$ は下記 のように表わされる。

$$
\begin{aligned}
& \alpha=\frac{m X^{2}}{\int_{0}^{2 s} \rho\left[X_{1}+\left(X-X_{1}\right) \frac{y}{s}\right]^{2} d y}=\frac{X^{2}}{X^{2}+\frac{1}{3}\left(X-X_{1}\right)^{2}} \\
& { }_{i} \alpha_{b}=\frac{X \cdot X_{1}}{X^{2}+\frac{1}{3}\left(X-X_{1}\right)^{2}}
\end{aligned}
$$

Fig.9 R RCD 機構の有効係数 $r_{e f}$ をロッキング半径と重心高さ の比 $R / s$ に対して示す。式(48)に示すように、 $r_{e f}$ はロッキング半 径 $\mathrm{R}$ に対して隅関数となっており、縦軸に対して半分を示した。 変形制御壁の剛性 $k_{c}$ に対して斜柱の断面剛性 $E A$ が大きいほど、 $\mathrm{RCD}$ 機構の塔状比 $2 s / L$ が小さいほど、 $r_{e f}$ が大きい。 $r_{e f}$ を大き くするために、 $k_{c}$ に対して斜柱の断面剛性 $E A$ を大きくする必要 がある。

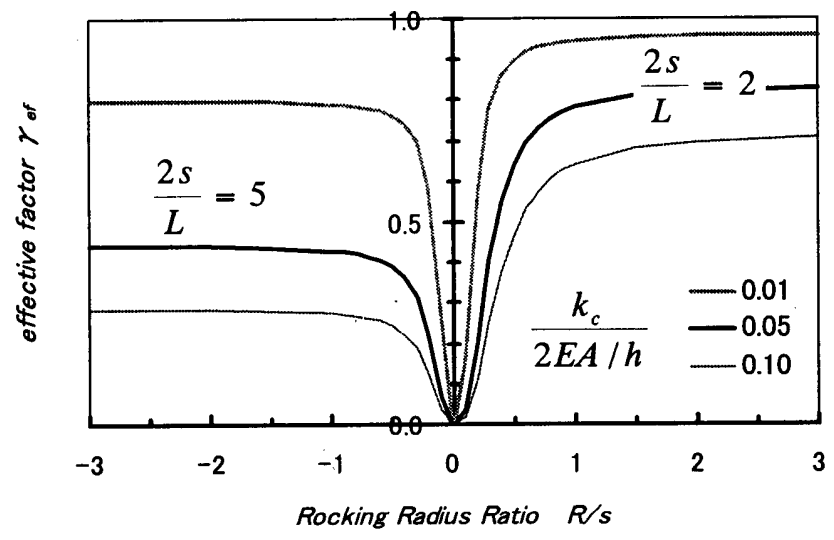

Fig.9 Effective Factor of RCD Mechanism
Fig.10に RCD 構造の刺激関数 $\left({ }_{i} \alpha,{ }_{i} \alpha_{b}\right)$ 及び固有周期 $\left(T_{1}, T_{2}\right)$ とロッキング半径と重心高さの比 $R / s$ との関係を示す。

$\mathrm{RCD}$ 構造の振動特性は主体構造の剛性分布 $\left(k_{1}, k s^{2}\right) 、 \mathrm{RCD}$ 機 構の塔状比 $2 s / L$ 及び剛性 $\left(k_{c}, E A / h\right)$ 、更に、ロッキング半径 と重心高さの比 $R / s$ に影響され、構造規模と設計目標を想定しな いと、比較検討は難しい。ここでは、 $2 s / L=5$ 、主体構造の剛性 を $2 \pi \sqrt{m / k}=1 s$ となるように設定し、また、変形制御壁の剛性 を $k_{c} / k=20$ とし、 $\mathrm{RCD}$ 機構の剛性比 $\left(k_{c} h /(2 E A)\right)$ 及び主体 構造の剛性比 $\left(k_{1} / k\right)$ をパラメータとした。

図中では、ロッキング半径が無限大、すなわちピロティー構造 の刺激関数 $\left({ }_{s f} \alpha,{ }_{s f} \alpha_{b}\right)$ と固有周期 $\left({ }_{s f} T_{1},{ }_{s f} T_{2}\right)$ 、並びに RCD 機 構の剛性が無限大とした場合の刺激関数 $\left(\alpha, \alpha_{b}\right.$ 、式 16) と固有 周期 $\left(T_{\theta} 、\right.$ 式 34) も併せて示した。

まず、ピロティー構造と比較すると、RCD 構造では振動モード と固有周期の制御が可能である。 RCD 構造の振動特性に対してロ ッキング半径と重心高さの比 $R / s$ の影響が特に大きい。 $R / s<0$ の 場合、 RCD 構造の振動モ一ドがほほ $R / s$ に決められ、 1 次固有 周期 $T_{1}$ が長くなり、 2 次固有周期 $T_{2}$ が短くなっている。 $R / s>2$ の 場合、 $\mathrm{RCD}$ 構造の振動モードは $R / s$ のほかに、 $\mathrm{RCD}$ 機構の剛性 比 $\left(k_{c} h /(2 E A)\right)$ と主体構造の剛性比 $\left(k_{1} / k\right)$ の影響も大きく、 $T_{1}$ が短くなり、 $T_{2}$ が長くなる傾向が見られる。 $0<R / s<2 、$ すなわち、ロッキング中心が主体構造の高さの範囲内にある場合、 2 次モードが大きくなり、また、 2 次固有周期 $T_{2}$ が 1 次固有周期 $T_{1}$ に接近する傾向が見られる。

次に、 RCD 機構の剛性の影響を見るために、 RCD 構造の 1 次 モードについて、RCD 機構の剛性が無限大とした場合の刺激関数 $\left(\alpha, \alpha_{b}\right)$ と固有周期 $T_{\theta}$ と比較する。主体構造の剛性比が小さい ケース (a)と (c)において $\left(k_{1} / k=1\right) 、 \mathrm{RCD}$ 機構の剛性が変化して も、1 次振動モードの形状の変化が小さく、1 次固有周期 $T_{1}$ もほ ぼ剛な RCD 機構モデルで評価できる。しかし、剛性比が大きい ケース(b)と(d)において $\left(k_{1} / k=5\right) 、 R / s>0$ の場合、 $\mathrm{RCD}$ 機構 の 1 次振動モ一ドと 1 次固有周期が大きく変化し、 $\mathrm{RCD}$ 機構の剛 性比 $k_{c} h /(2 E A)$ の影響も大きい。

以上のように、RCD 構造は一種のモード制御構造である。しか し、その振動特性は剛な RCD 機構モデルのようにロッキング半 径と重心高さの比 $R / s$ だけでなく、 $\mathrm{RCD}$ 機構の剛性と主体構造 の剛性などの影響も大きく、応答の評価には各次モードの影響を 正確的に考虑する必要がある。

ここでは詳しく検討しないが、Fig.10 のケース(b)のように、 $0<R / s<2$ において、重心位置での 1 次と 2 次の刺激関数 $\left({ }_{1} \alpha,{ }_{2} \alpha\right)$ が共に 0.5 程度、且つ 2 次固有周期 $T_{2}$ が 1 次固有周期 $T_{1}$ に近づく領域が存在する。特殊なケースとして、RCD 構造で は、 ${ }_{1} \alpha={ }_{2} \alpha=0.5$ とすることができる。この場合、式(57)より $X_{1} / X=1 \pm \sqrt{3}$ となり、各次の回転成分がもっとも大きい。しか し、各次固有周期及び隇衰定数の差の程度によって、1 次モード と 2 次モードがどのように累加あるいは相殺するかは重要な検討 課題である。更に、制御しようとする応答量（加速度、変位など） とその位置によって、 $\mathrm{RCD}$ 構造の適用も異なると考えられる。 


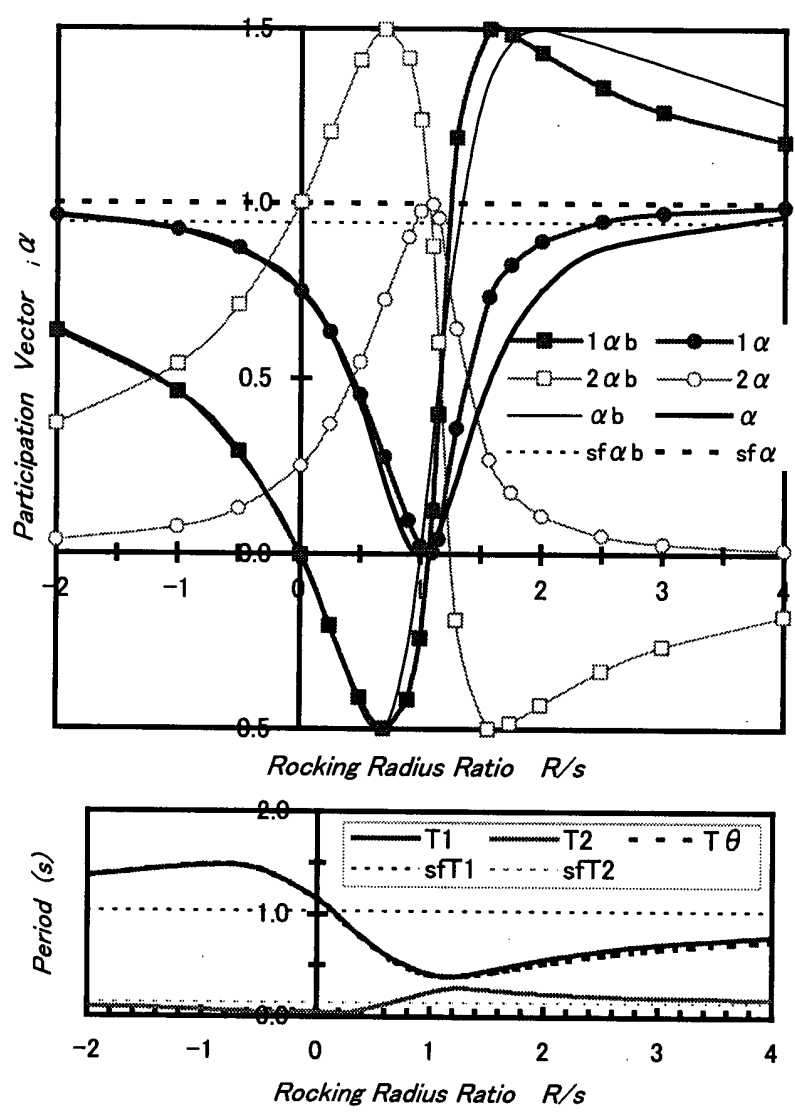

(a) $k_{c} h /(2 E A)=0.01, k_{1} / k=1$
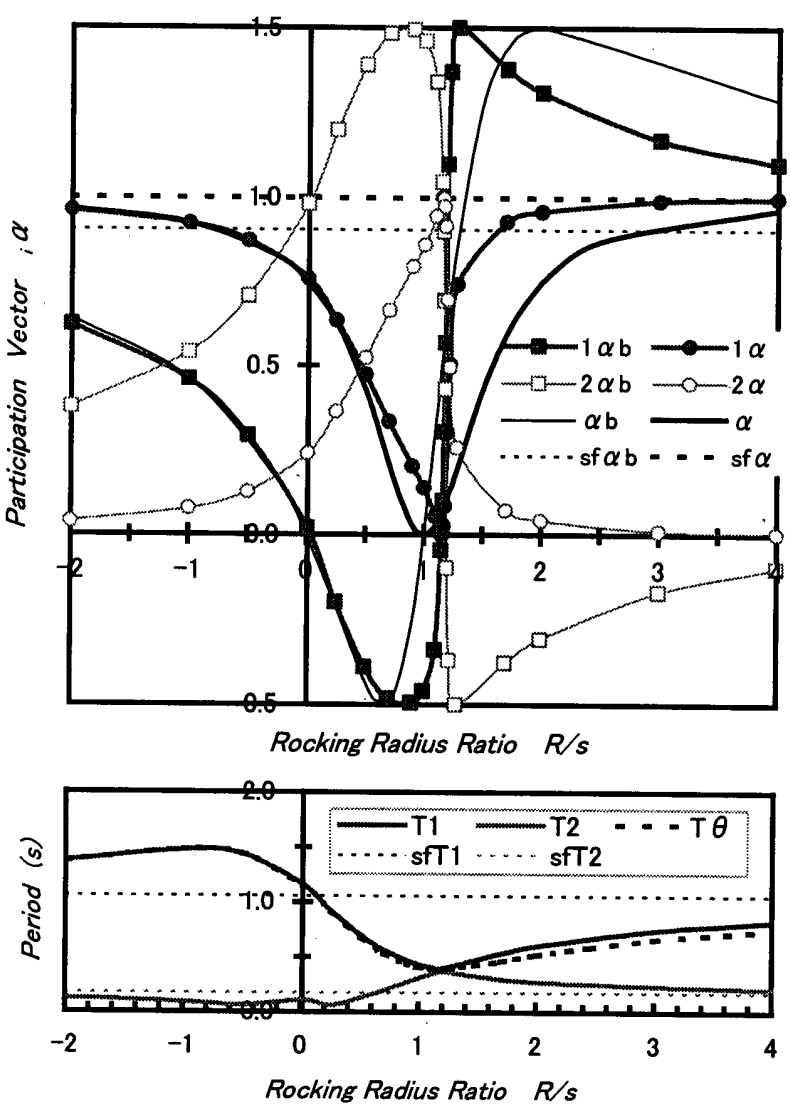

(c) $k_{c} h /(2 E A)=0.05, k_{1} / k=1$
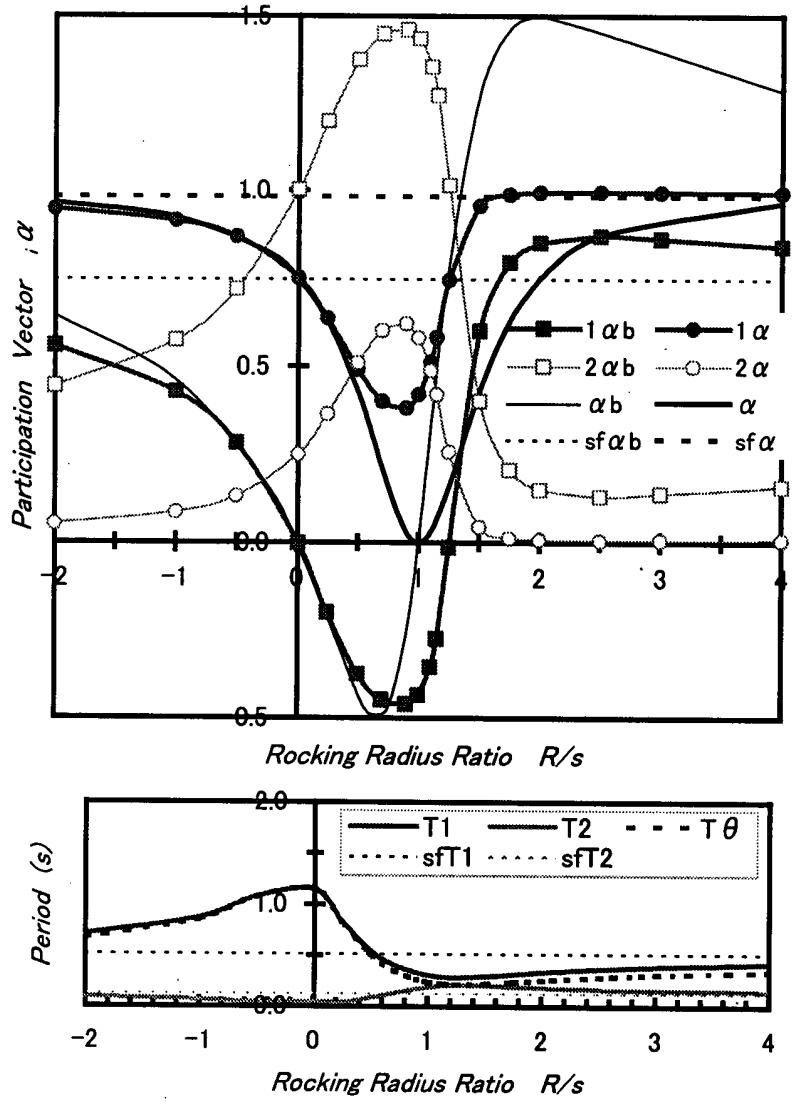

(b) $k_{c} h /(2 E A)=0.01, k_{1} / k=5$
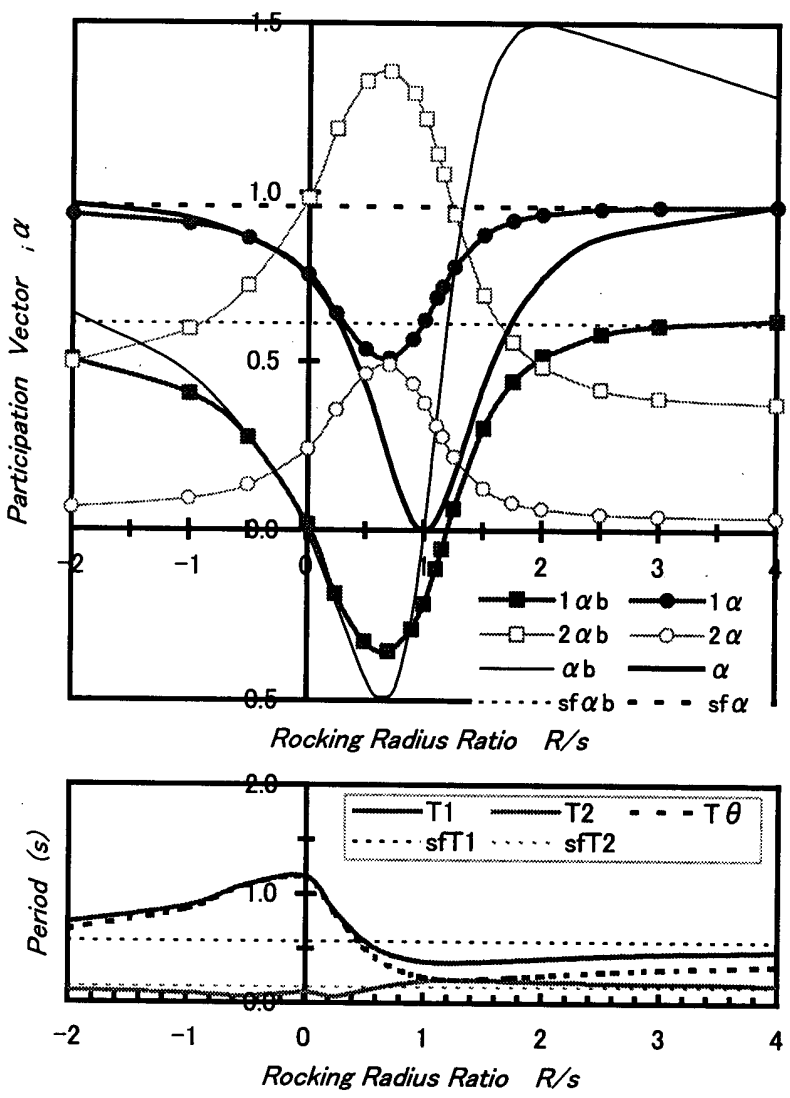

(d) $k_{c} h /(2 E A)=0.05, k_{1} / k=5$

Fig.10 Participation Vector and Vibration Period of RCD Structure 

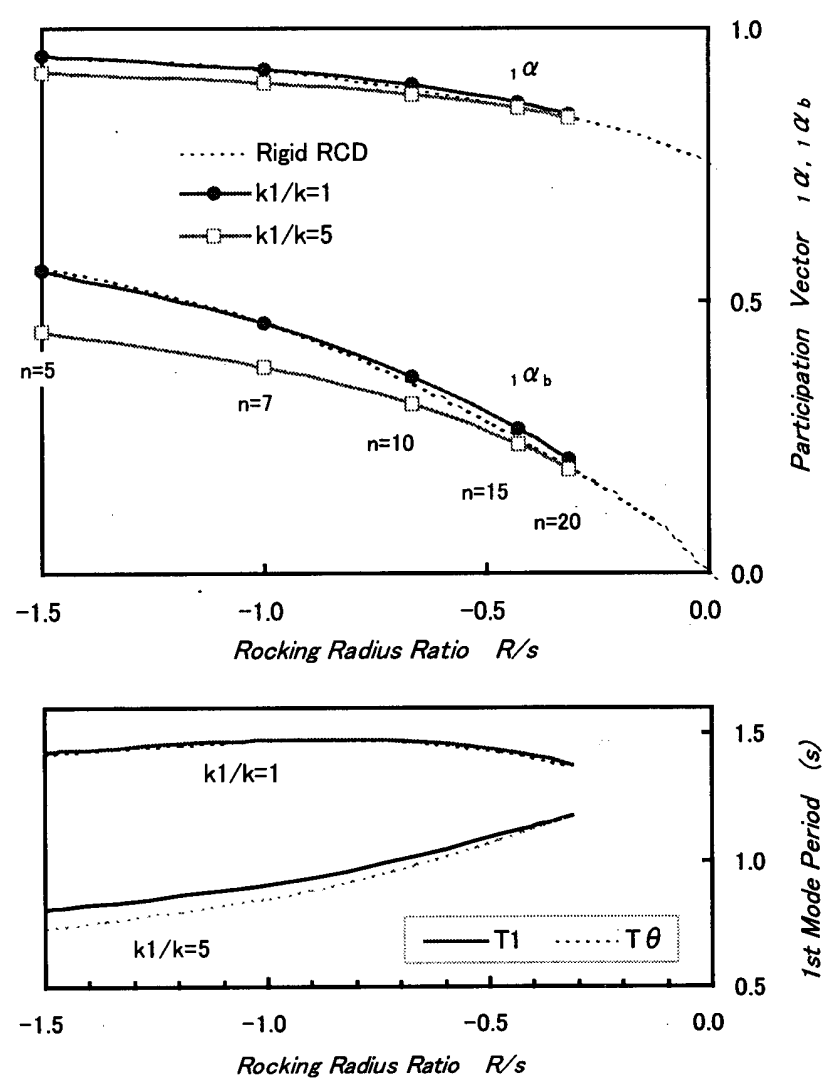

Fig.11 Vibration of Displacement Distribution System

\section{4 変形配分型構造システム}

今まで、免震構造のように矩形に近い 1 次振動モードを示す損 傷集中型構造と、梁降伏機構や基礎回転型機構など逆三角形 1 次 振動モードを示す損傷分散機構 ${ }^{4), 5)}$ の、両極端な構造システムし か提案・適用されていない。 $\mathrm{RCD}$ 構造は任意の振動モ一ドを設定 できる構造システムである。特に、ロッキング半径と重心高さの 比 $R / s$ が桑の值の場合、 $\mathrm{RCD}$ 構造の 1 次モードが卓越し、応答 変形を上部主体構造と第 1 階に配分する変形配分型構造システム を構築することが可能である。

ここで例として、1 階と上階の階高が等しい $\mathrm{n}$ 階建の建物に対 して検討を行う。

まず、剛な RCD 機構モデルの場合、 1 階の層間変形角は上階の 層間変形角の $-R / h$ 倍となるので、 $R / h=-3$ とする。すなわち、 1 階の層間変形角は上階の層間変形角の 3 倍程度と設定する。ま た、 $\mathrm{RCD}$ 機構において $L / h=2$ 、変形制御壁の剛性を $k_{c} / k=10$ とする。

次に、 $\mathrm{RCD}$ 機構の剛性比を $k_{c} h /(2 E A)=0.5 /(n-1)$ とし、上 階主体構造の階数に反比例とする。なお、主体構造の剛性を $2 \pi \sqrt{m / k}=1 s$ となるように設定した。

Fig.11 にこのように設定した RCD 構造の 1 次モードの刺激関 数及び固有周期を示す。
主体構造の剛性比 $k_{1} / k$ が 5 の場合、 1 次振動モードは剛な RCD 機構モデルと若干異なるが、 $k_{1} / k$ が 1 の場合、変形配分型構造 の振動特性を剛な RCD 機構モデルで評価できる。すなわち、1 次モードを式(16)、1 次固有周期を式(34)で評価できる。更に、建 物の応答変位と重心の応答加速度を 2.3 節の方法（式 25、27）で 評価できるが、 1 次の刺激関数が 1 と大きく異なる位直での応答 加速度は 2 次モードの影響も考慮する必要がある。

上記の変形配分型構造システムでは、式(33)に示すように、1 次モードに対応する有効剛性は上階の剛性及び 1 階の剛性で決め られ、ピロティー建物のように第 1 階の変形の発散現象を生じる ことがない。

変形配分型構造システムのもう一つの特徴は、エネルギー吸収 装置を比較的変形が大きい第 1 階に集中配置できる点を挙げるこ とができる。今後、減衰を考慮し、建物モデルを用いた検討も必 要である。

\section{4. まとめ}

本報では建物の振動モードを任意に設定できる RCD 機構と $\mathrm{RCD}$ 構造システムを提案し、剛体モテル及び 1 質点 2 自由度モデ ルを用いてその原理と振動性状を検討した。 RCD 構造は従来の損 傷集中型構造と損傷分散型構造を連続した構造システムに広げ、構 造設計と構造性能の多様性を実現し、様々な可能性が考えられる。 その一例として応答変形を第 1 階と上階に配分する変形配分型構 造システムを提案した。

$\mathrm{RCD}$ 機構及び RCD 構造は一つの新しい構造システムであり、 それ自身あるいは従来の構造システムとの並列もしくは直列で、 アクティブ制振も含め制振構造への展開が期待できると思われる。 本報では、基本的な原理を説明するために、無減衰の 1 質点モ テルを用いた。今後、実際の建物に即した解析モテルを用い、RCD 機構を構成する斜柱及び変形制御壁の応力並びに必要剛性と必要 強度などを検討し、報告する予定である。

\section{参考文献 :}

1) 石丸辰治 : 構造物の地震応答制御概論、応用力学シリーズ 2 「建築構造 物の設計力学と制御動力学小、日本建築学会、1994年9月、pp.187〜240

2)（田治見宏 : 建築振動学、コロナ社、1965年

3) 柴田明徳 : 最新耐震構造解析、森北出版、1981年

4) Goodsir,W.J., Paulay,T., and Carr,A.J. : A Study of the Inelastic Seismic Response of Reinforced Concrete Coupled Frame-Shear Wall Structures, Bulletin of the New Zealand National Society for Earthquake Engineering, Vol.16,No.3, September 1983, pp.185-200.

5) 秋山宏、高橋誠：損傷分散型多首骨組のDs值、日本建築学会論文報告集、 第341号、1984年7月、pp.54 61

6) 張富明 : 回転中心指定型ロッキング機構とそれを用いた構造物の応答性 状、松村組技術研究所年報、Vol.8、2000年10月、pp.9〜16 